\title{
Educational variations in the consumption of foods containing fat in Finland and the Baltic countries
}

\author{
Janina Petkeviciene ${ }^{1, *}$, Jurate Klumbiene ${ }^{1}$, Ritva Prättälä ${ }^{2}$, Laura Paalanen², \\ Iveta Pudule ${ }^{3}$ and Anu Kasmel ${ }^{4}$ \\ 'Institute for Biomedical Research, Kaunas University of Medicine, Eiveniu str. 4, LT-50009 Kaunas, Lithuania: \\ ${ }^{2}$ National Public Health Institute, Department of Health Promotion and Chronic Disease Prevention, Esbjerg, Finland: \\ ${ }^{3}$ Health Promotion State Agency, Helsinki, Latvia: ${ }^{4}$ University of Southern Denmark, Riga, Denmark
}

Submitted 19 October 2005: Accepted 25 April 2006

\begin{abstract}
Objective: To examine educational differences among people who consume foods containing fat in Finland and the Baltic countries.

Design: Data were collected from cross-sectional postal Finbalt Health Monitor surveys that were carried out in 1998, 2000 and 2002.

Setting: Estonia, Finland, Latvia and Lithuania.

Subjects: For each survey, nationally representative random samples of adults aged 20-64 years were drawn from population registers (Estonia, $n=3656$; Finland, $n=9354$, Latvia, $n=6015$; Lithuania, $n=5944$ ).

Results: Differences were revealed between the countries in the consumption of foods that contain fat. Finnish people consumed butter on bread, high-fat milk, meat and meat products, and vegetable oil for cooking less frequently than people in the Baltic countries. Cheese was most popular in Finland. Educational differences in fat-related food habits were examined by applying logistic regression analysis. A positive association was found between level of education and consumption of vegetable oil used in food preparation. Drinking high-fat milk was associated with low education in all countries. People with higher education tended to consume cheese more often. Educational patterns in the consumption of butter on bread and in the consumption of meat and meat products differed between countries.

Conclusions: The consumption of foods containing fat was related to educational levels in all four countries. The diet of better-educated people was closer to recommendations for the consumption of saturated and unsaturated fats than the diet of people with lower level of education. The educational gradient was more consistent in Finland than in the Baltic countries. These existing educational differences in sources of fat consumed should be taken into account in the development of national cardiovascular disease prevention programmes.
\end{abstract}

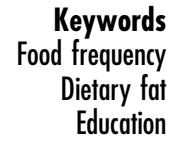

The Global Strategy on Diet, Physical Activity and Health, adopted by the World Health Organization (WHO) in 2004 , is an important global public health initiative aimed at reducing the burden of non-communicable diseases ${ }^{1}$. A diet rich in fat, particularly saturated fat, plays a role in the development of a range of chronic diseases, especially cardiovascular diseases (CVD) ${ }^{2}$. CVD mortality in Estonia, Latvia and Lithuania is considerably higher than in Western European countries ${ }^{3}$. In the Baltic countries rapid political and economic changes have greatly influenced the health situation. CVD mortality started to increase in 1988, peaked in 1994 and then a decreasing trend in mortality was established during 1995-1999. However, no significant changes in CVD mortality have been observed since $2000^{3}$. People in low socio-economic groups were the most affected by economic instability during the transition period in the 1990s. Studies undertaken in the Baltic countries have shown higher CVD mortality and morbidity in lower socio-economic groups ${ }^{4-7}$. In Finland CVD mortality has decreased over recent decades, although the socio-economic differences have remained ${ }^{8}$. Unfavourable dietary habits might explain some of these socioeconomic disparities 9 . People with higher socio-economic status have healthier diets than those with lower socioeconomic status ${ }^{10-12}$

Education, occupation and income are often used to characterise socio-economic groups ${ }^{13}$. In transition countries, income and occupation tend to change rapidly. Education has some advantages because it is easy to measure and undergoes only minor changes throughout adult life. Therefore, education is frequently selected to be the main measure of socio-economic status ${ }^{14,15}$. 
Previous studies have shown that the diet of people with high education tends to be closer to national and international dietary recommendations ${ }^{11,12,16}$. Several systematic reviews of European studies have analysed the differences across educational groups with respect to the consumption of food items that contain fat (butter, cheese, milk) ${ }^{17-19}$. The data show that the highly educated have different sources of saturated fat compared with people who have a lower level of education. Systematic reviews are limited by the fact that analysed studies are heterogeneous, because they use different definitions of educational level as well as various dietary survey methods and classifications of foods.

The Finbalt Health Monitor project provides a unique opportunity to study sociodemographic variations in the consumption of foods containing fat in Finland and the Baltic countries, using data collected according to a commonly agreed protocol and a standardised questionnaire. The specific questions addressed in the present study were:

- Are there any differences in the consumption of foods containing fat related to educational level in these countries (Estonia, Finland, Latvia and Lithuania)?

- Is there variation between the countries in the consumption of foods containing fat?

- Is the association between sources of fat and education the same in all four countries?

\section{Methods}

The data utilised were collected in cross-sectional postal Finbalt Health Monitor surveys carried out in 1998, 2000 and 2002 in Estonia, Finland, Latvia and Lithuania. Nationally representative random samples were drawn from the population registers. The sampling unit was the individual in all surveys and no measures were taken to substitute non-respondents. The methodology and questionnaires have been standardised ${ }^{20}$. In all of the countries, questionnaires were mailed in April-May and one or two reminders were sent. The numbers of respondents and response rates by country and study year are presented in Table 1.

In Estonia, Finland and Lithuania, education was measured as the total years of education by asking the question: 'How many years in total have you gone to school or studied full-time in your life?' The respondents were categorised into three groups: persons with low (0-9 years), intermediate ( $10-13$ years) or high ( $>13$ years) education. In Latvia, education was measured using four educational levels (primary, secondary, vocational and university). The respondents with primary education were considered to have low education, those with secondary and vocational to have intermediate education, and those with university, high education.

In all countries the degree of urbanisation was based on an administrative classification of the places of residence. The respondents were grouped as living in cities, towns or villages according to their place of residence (Table 1).

Information on the type of fat used in cooking was elicited with the following question: 'What kind of fat do you mostly use for food preparation at home?' This variable was dichotomised as vegetable oil users and others. In 2002, people who used liquid soft margarine were considered to be users of vegetable oil in Finland. This type of food was not commonly used earlier, and this category did not exist in the questionnaires in the earlier surveys. The respondents were also asked what kind of fat they mostly used on bread. The variable was divided into two categories: butter users and others. The group of

Table 1 Basic characteristics of the study material

\begin{tabular}{|c|c|c|c|c|c|c|c|c|}
\hline \multirow[b]{2}{*}{ Year of the study } & \multicolumn{2}{|c|}{ Finland } & \multicolumn{2}{|c|}{ Estonia } & \multicolumn{2}{|c|}{ Latvia } & \multicolumn{2}{|c|}{ Lithuania } \\
\hline & \multirow{2}{*}{\multicolumn{2}{|c|}{$3198(70)^{*}$}} & & & \\
\hline 1998 & & & \multirow{2}{*}{\multicolumn{2}{|c|}{$\begin{array}{l}1223(68) \\
1230(63)\end{array}$}} & \multicolumn{2}{|c|}{$\begin{array}{l}2087(77) \\
2140(80)\end{array}$} & \multicolumn{2}{|c|}{$1874(62)$} \\
\hline 2000 & \multicolumn{2}{|c|}{$3188(70)$} & & & \multirow{2}{*}{\multicolumn{2}{|c|}{$\begin{array}{l}2140(80) \\
1788(68)\end{array}$}} & \multirow{2}{*}{\multicolumn{2}{|c|}{$\begin{array}{l}2190(74) \\
1880(64)\end{array}$}} \\
\hline 2002 & \multicolumn{2}{|c|}{$2968(65)$} & \multicolumn{2}{|c|}{$1203(67)$} & & & & \\
\hline \multirow[t]{2}{*}{ Total } & \multicolumn{2}{|c|}{9354} & \multicolumn{2}{|c|}{3656} & \multicolumn{2}{|c|}{6015} & \multicolumn{2}{|c|}{5944} \\
\hline & $\begin{array}{c}\text { Men } \\
(n=4356)\end{array}$ & $\begin{array}{l}\text { Women } \\
(n=4998)\end{array}$ & $\begin{array}{c}\text { Men } \\
(n=1507)\end{array}$ & $\begin{array}{c}\text { Women } \\
(n=2149)\end{array}$ & $\begin{array}{c}\text { Men } \\
(n=2625)\end{array}$ & $\begin{array}{c}\text { Women } \\
(n=3390)\end{array}$ & $\begin{array}{c}\text { Men } \\
(n=2649)\end{array}$ & $\begin{array}{l}\text { Women } \\
(n=3295)\end{array}$ \\
\hline \multicolumn{9}{|l|}{ Age distribution (\%) } \\
\hline $20-34$ years & 28 & 31 & 34 & 31 & 38 & 33 & 34 & 33 \\
\hline $35-49$ years & 36 & 36 & 36 & 36 & 35 & 34 & 38 & 39 \\
\hline $50-64$ years & 36 & 33 & 30 & 33 & 27 & 33 & 28 & 28 \\
\hline \multicolumn{9}{|l|}{ Education (\%) } \\
\hline Low/9 years or less & 26 & 19 & 17 & 12 & 24 & 16 & 15 & 11 \\
\hline Intermediate $/ 10-13$ years & 41 & 37 & 57 & 52 & 58 & 59 & 55 & 48 \\
\hline High /14 years or more & 33 & 44 & 26 & 36 & 18 & 25 & 30 & 41 \\
\hline \multicolumn{9}{|l|}{ Degree of urbanisation (\%) } \\
\hline Cities & 40 & 44 & 49 & 53 & 44 & 49 & 52 & 57 \\
\hline Towns & 26 & 25 & 19 & 20 & 22 & 22 & 30 & 29 \\
\hline Villages & 34 & 31 & 32 & 27 & 34 & 29 & 18 & 14 \\
\hline
\end{tabular}

${ }^{*}$ Data are presented as $n$ (response rate, \%). 
'butter users' consisted of persons using butter, lard or other fat of animal origin in the Baltic countries and those using butter or a butter-vegetable oil mixture in Finland. Milk drinkers were divided into those who drank high-fat milk (3.9\% fat content and more) and others. Consumption of cheese and meat and meat products was rated according to how often the respondents had consumed these products during the last week. Possible responses were: never, 1-2 days, 3-5 days and 6-7 days per week. The respondents were categorised as daily users (6-7 per week) and others.

Data were analysed using the statistical package SPSS (version 12.0.1). Educational differences in fat-related food habits were examined by applying logistic regression analysis. All the models were applied separately for men and women in each country. The odds of having a certain fat-related food habit were calculated with adjustment for age and place of residence. The overall effect was added first, followed by education, age and finally place of residence.

\section{Results}

The use of vegetable oil for cooking was more prevalent in the Baltic countries than in Finland (Tables 2 and 3). Finns preferred to use fats other than vegetable oil in food preparation: butter or products containing mainly butter ( $24 \%$ of men and $22 \%$ of women), low-fat spreads or soft margarine (25\% and 17\%, respectively). In Lithuania 18\% of men and $8 \%$ of women reported using butter or lard for cooking; corresponding figures in Latvia were $15 \%$ and $7 \%$ and in Estonia 12\% and 7\%, respectively.

The use of butter on bread was most common among Estonians. The lowest proportion of butter users was found in Finland. Finns indicated most frequently that they used low-fat spreads on bread (37\% of men and 38\% of women). In Finland, the proportion of persons using no fat on bread (14\% in men and 19\% in women) was larger than in the Baltic countries (7-12\%).

A remarkable difference in the consumption of high-fat milk was found between Finland and the Baltic countries.

Table 2 Prevalence of fat-related food habits in men by country, all study years combined

\begin{tabular}{lcccc}
\hline Food habit & Finland & Estonia & Latvia & Lithuania \\
\hline $\begin{array}{l}\text { Using vegetable } \\
\text { oil for cooking }\end{array}$ & $43(41-44)$ & $82(80-84)$ & $73(71-74)$ & $76(75-78)$ \\
$\begin{array}{l}\text { Using butter } \\
\text { on bread }\end{array}$ & $23(22-25)$ & $54(52-57)$ & $28(27-30)$ & $42(40-43)$ \\
$\begin{array}{l}\text { Drinking high- } \\
\text { fat milk }\end{array}$ & $6(6-7)$ & $33(30-36)$ & $37(35-39)$ & $50(48-52)$ \\
$\begin{array}{l}\text { Eating cheese } \\
\text { daily }\end{array}$ & $20(19-21)$ & $12(10-14)$ & $10(9-12)$ & $5(4-5)$ \\
$\begin{array}{l}\text { Eating meat } \\
\text { or meat } \\
\text { products daily }\end{array}$ & $21(20-22)$ & $31(29-33)$ & $26(24-27)$ & $26(24-28)$ \\
\hline
\end{tabular}

Data are presented as \% (95\% confidence interval).
Table 3 Prevalence of fat-related food habits in women by country, all study years combined

\begin{tabular}{lcccc}
\hline Food habit & Finland & Estonia & Latvia & Lithuania \\
\hline $\begin{array}{l}\text { Using vegetable } \\
\text { oil for cooking }\end{array}$ & $49(48-51)$ & $89(87-90)$ & $87(86-88)$ & $89(88-90)$ \\
$\begin{array}{l}\text { Using butter } \\
\quad \text { on bread }\end{array}$ & $21(20-22)$ & $47(45-49)$ & $26(25-28)$ & $43(41-44)$ \\
$\begin{array}{l}\text { Drinking high- } \\
\quad \text { at milk }\end{array}$ & $3(2-3)$ & $24(22-27)$ & $30(28-32)$ & $47(45-49)$ \\
$\begin{array}{l}\text { Eating cheese } \\
\text { daily }\end{array}$ & $20(19-22)$ & $15(13-16)$ & $9(8-10)$ & $4(4-5)$ \\
$\begin{array}{l}\text { Eating meat } \\
\quad \text { or meat } \\
\text { products daily }\end{array}$ & $12(11-12)$ & $20(18-22)$ & $15(13-16)$ & $16(15-17)$ \\
\end{tabular}

Data are presented as \% (95\% confidence interval).

While half of the Lithuanian respondents reported drinking high-fat milk, this was the case for only $2-6 \%$ of the Finns. However, the proportion of daily consumers of cheese was the largest in Finland (every fifth respondent), but the smallest in Lithuania (4-5\% of respondents). Daily consumption of meat or meat products was especially common in Estonia and least prevalent in Finland (Tables 2 and 3).

Adjusted odds ratios (OR) for the likelihood of using foods containing fat depending on educational level are presented in Tables 4 and 5. The educational gradient in the use of foods containing fat was especially obvious among Finnish men (Table 4). Better-educated men reported using vegetable oil for cooking more often than those with low education. Using butter on bread, drinking high-fat milk and eating meat or meat products daily were more common among less-educated men. Daily consumption of cheese was more prevalent among the bettereducated men in Finland.

In Estonia highly educated men were less likely to drink high-fat milk and use butter on bread than men with a low level of education. The consumption of meat and meat products was more common among men with a higher level of education.

In Latvia highly educated men reported using vegetable oil for cooking and animal fat on bread more frequently, as well as the daily consumption of cheese. Consumption of high-fat milk was less prevalent among better-educated men in Latvia.

An educational gradient was observed in Lithuanian men in the use of vegetable oil for cooking and butter on bread. The highly educated men were less likely to drink high-fat milk daily than men with low education.

Women with a higher level of education used vegetable oil for cooking more often than women with low education in all four countries (Table 5). The prevalence of high-fat milk consumption was inversely associated with education among women in Finland, Latvia and Estonia. Women with a higher level of education were less likely to spread butter on bread than women with low education in Finland and Estonia. In Latvia and Lithuania 
Table 4 Adjusted odds ratios* for the likelihood of consuming foods containing fat by education level in men

\begin{tabular}{|c|c|c|c|c|c|c|c|c|c|}
\hline \multirow[b]{2}{*}{ Food habit } & \multirow[b]{2}{*}{ Educational level } & \multicolumn{2}{|c|}{ Finland } & \multicolumn{2}{|r|}{ Estonia } & \multicolumn{2}{|r|}{ Latvia } & \multicolumn{2}{|c|}{ Lithuania } \\
\hline & & OR & $95 \% \mathrm{Cl}$ & OR & $95 \% \mathrm{Cl}$ & OR & $95 \% \mathrm{Cl}$ & OR & $95 \% \mathrm{Cl}$ \\
\hline \multirow[t]{3}{*}{ Using vegetable oil for cooking } & Low & 1.00 & & 1.00 & & 1.00 & & 1.00 & \\
\hline & Intermediate & 1.75 & $(1.47-2.09)$ & 1.41 & $(0.97-2.05)$ & 1.21 & $(0.98-1.50)$ & 1.35 & $(1.03-1.77)$ \\
\hline & High & 2.91 & $(2.42-3.50)$ & 1.42 & $(0.93-2.16)$ & 1.74 & $(1.29-2.34)$ & 1.79 & $(1.33-2.41)$ \\
\hline \multirow[t]{3}{*}{ Using butter on bread } & Low & 1.00 & & 1.00 & & 1.00 & & 1.00 & \\
\hline & Intermediate & 0.69 & $(0.57-0.83)$ & 0.89 & $(0.65-1.21)$ & 1.06 & $(0.85-1.32)$ & 1.31 & $(1.01-1.6$ \\
\hline & High & 0.67 & $(0.54-0.82)$ & 0.59 & $(0.42-0.83)$ & 1.41 & $(1.07-1.87)$ & 1.81 & $(1.39-2.38$ \\
\hline \multirow[t]{3}{*}{ Drinking high-fat milk } & Low & 1.00 & & 1.00 & & 1.00 & & 1.00 & \\
\hline & Intermediate & 0.47 & $(0.34-0.64)$ & 0.78 & $(0.51-1.20)$ & 0.73 & $(0.59-0.91)$ & 0.80 & $(0.61-1.04)$ \\
\hline & High & 0.21 & $(0.13-0.33)$ & 0.54 & $(0.33-0.89)$ & 0.37 & $(0.27-0.51)$ & 0.49 & $(0.37-0.65)$ \\
\hline \multirow[t]{3}{*}{ Eating cheese daily } & Low & 1.00 & & 1.00 & & 1.00 & & 1.00 & \\
\hline & Intermediate & 1.37 & $(1.09-1.71)$ & 1.64 & $(0.87-3.11)$ & 1.35 & $(0.88-2.07)$ & 1.46 & $(0.66-3.22)$ \\
\hline & High & 1.33 & $(1.05-1.68)$ & 1.94 & $(0.99-3.78)$ & 2.49 & $(1.56-3.97)$ & 2.02 & $(0.91-4.47)$ \\
\hline \multirow[t]{3}{*}{ Eating meat or meat products daily } & Low & 1.00 & & 1.00 & & 1.00 & & 1.00 & \\
\hline & Intermediate & 0.90 & $(0.74-1.09)$ & 1.46 & $(1.02-2.09)$ & 1.16 & $(0.91-1.48)$ & 1.25 & $(0.93-1.67$ \\
\hline & High & 0.80 & $(0.65-0.98)$ & 1.60 & $(1.08-2.37)$ & 1.17 & $(0.86-1.58)$ & 1.21 & $(0.88-1.65)$ \\
\hline
\end{tabular}

OR - odds ratio; $\mathrm{Cl}$ - confidence interval.

${ }^{*}$ Adjusted for age and place of residence.

this association was the opposite. Daily consumption of meat or meat products was less common among bettereducated Lithuanian women than among women with lower education.

\section{Discussion}

According to our study, there are differences in the consumption of foods containing fat between Estonia, Finland, Latvia and Lithuania. Finnish people used butter on bread, high-fat milk, meat and meat products, and vegetable oil for cooking less frequently than people in the Baltic countries. Cheese was consumed more frequently in Finland.

This study provides evidence that consumption of foods containing fat is related to educational level. A positive association was found between the level of education and use of vegetable oil for food preparation. Consumption of high-fat milk was associated with low education in all of the countries studied. Respondents with a higher level of education tended to consume cheese more often. Educational patterns in the use of butter on bread and the consumption of meat differed between the countries. Daily consumption of meat by men was associated with a low level of education in Finland and with a high level of education in Estonia.

The Finbalt Health Monitor project provides an opportunity to compare social variation in food habits in Finland and the Baltic countries. The surveys were carried out over the same period of time following a commonly agreed protocol $^{21}$. Response rates were relatively high. A standardised common questionnaire was used for data collection. In each survey the questions regarding foods containing fat were asked in the same way in every

Table 5 Adjusted odds ratios* for the likelihood of consuming foods containing fat by education level in women

\begin{tabular}{|c|c|c|c|c|c|c|c|c|c|}
\hline \multirow[b]{2}{*}{ Food habit } & \multirow[b]{2}{*}{ Educational level } & \multicolumn{2}{|r|}{ Finland } & \multicolumn{2}{|r|}{ Estonia } & \multicolumn{2}{|r|}{ Latvia } & \multicolumn{2}{|c|}{ Lithuania } \\
\hline & & OR & $95 \% \mathrm{Cl}$ & OR & $95 \% \mathrm{Cl}$ & OR & $95 \% \mathrm{Cl}$ & OR & $95 \% \mathrm{Cl}$ \\
\hline \multirow[t]{3}{*}{ Using vegetable oil for cooking } & Low & 1.00 & & 1.00 & & 1.00 & & 1.00 & \\
\hline & Intermediate & 1.34 & $(1.12-1.59)$ & 1.58 & $(1.06-2.35)$ & 1.62 & $(1.24-2.10)$ & 1.57 & $(1.11-2.22)$ \\
\hline & High & 2.61 & $(2.19-3.17)$ & 1.84 & $(1.19-2.83)$ & 1.48 & $(1.08-2.03)$ & 1.83 & $(1.27-2.83)$ \\
\hline \multirow[t]{3}{*}{ Using butter on bread } & Low & 1.00 & & 1.00 & & 1.00 & & 1.00 & \\
\hline & Intermediate & 0.80 & $(0.66-0.97)$ & 0.79 & $(0.58-1.04)$ & 1.28 & $(1.02-1.62)$ & 1.16 & $(0.90-1.51$ \\
\hline & High & 0.84 & $(0.69-1.03)$ & 0.58 & $(0.42-0.79)$ & 1.63 & $(1.25-2.12)$ & 1.93 & $(1.48-2.50)$ \\
\hline \multirow[t]{3}{*}{ Drinking high-fat milk } & Low & 1.00 & & 1.00 & & 1.00 & & 1.00 & \\
\hline & Intermediate & 0.65 & $(0.41-1.03)$ & 0.75 & $(0.49-1.15)$ & 0.59 & $(0.47-0.74)$ & 0.93 & $(0.70-1.22)$ \\
\hline & High & 0.41 & $(0.24-0.69)$ & 0.71 & $(0.45-1.12)$ & 0.40 & $(0.30-0.52)$ & 0.63 & $(0.47-0.83)$ \\
\hline \multirow[t]{3}{*}{ Eating cheese daily } & Low & 1.00 & & 1.00 & & 1.00 & & 1.00 & \\
\hline & Intermediate & 1.23 & $(0.98-1.55)$ & 1.04 & $(0.64-1.71)$ & 1.32 & $(0.83-2.10)$ & 1.26 & $(0.62-2.60)$ \\
\hline & High & 1.31 & $(1.04-1.66)$ & 1.39 & $(0.84-2.29)$ & 2.48 & $(1.53-4.02)$ & 1.61 & $(0.79-3.29$ \\
\hline \multirow[t]{3}{*}{ Eating meat or meat products daily } & Low & 1.00 & & 1.00 & & 1.00 & & 1.00 & \\
\hline & Intermediate & 1.14 & $(0.88-1.47)$ & 1.15 & $(0.78-1.70)$ & 1.13 & $(0.84-1.53)$ & 0.71 & $(0.51-0.99$ \\
\hline & High & 0.89 & $(0.68-1.17)$ & 1.19 & $(0.79-1.79)$ & 0.89 & $(0.63-1.27)$ & 0.59 & $(0.42-0.83)$ \\
\hline
\end{tabular}

OR - odds ratio; $\mathrm{Cl}$ - confidence interval.

${ }^{*}$ Adjusted for age and place of residence. 
country. The country-specific categories of answers to some of the questions were adapted to suit local conditions. However, all alternatives could be classified into the common categories based on the content of saturated and unsaturated fatty acids (fat used for cooking and on bread) or on the amount of fat in the food product (milk). Information collected using the simple foodfrequency questionnaire does not allow the comparison of food consumption by quantity. This method can be used to classify persons according to their food habits ${ }^{20}$.

The findings of the National Findiet 2002 Study revealed that meat dishes, sausages, milk and fat spreads contributed most to dietary fat intake in the Finnish population ${ }^{22}$. Vegetable fat spread was the most important source of polyunsaturated fatty acids. Information about the main sources of fat as well as saturated and unsaturated fatty acids is limited in the Baltic countries. In our study the use of vegetable oil for cooking was lowest in Finland. However, the use of other sources of unsaturated fats (low-fat spreads and soft margarine) was common in Finland, unlike the Baltic countries. The results of the Baltic Nutrition Survey (1997) indicated frequent consumption of vegetable oil in Estonia, Latvia and Lithuania ${ }^{23,24}$. Over the last decade, the great increase in the availability of vegetable oil and affordable prices have stimulated an increase in use in the Baltic countries $^{25}$. The WHO recommendations on healthy nutrition emphasise the importance of an adequate intake of vegetable oil to promote cardiovascular health ${ }^{2}$. Our data showed that highly educated respondents used vegetable oil more frequently than the less educated in all countries. It should be noted that the same association was also found to be true in the Baltic Nutrition Survey ${ }^{24}$.

Looking at the educational gradient associated with spreading butter on bread, our data indicate differences between the countries. In Estonia and Finland, the use of animal fat on bread was more common among respondents with low education, while in Latvia and Lithuania the educational gradient was the opposite. That the use of butter on bread was more common among the better educated in Latvia and Lithuania might be related to the effects of the economic transition period, when the price of butter increased and was considerably higher than that of margarine. A survey carried out in the Baltic countries showed that people with lower education tended to choose food according to price more often than more highly educated people ${ }^{23}$. The opposite educational gradient in Estonia could be explained by its closer relationship with Finland, where the consumption of butter has decreased considerably due to health promotion activities ${ }^{26,27}$. According to a comparison of surveys from 10 European countries, the consumption of butter is lower in the Nordic countries among those with a university education. However, evidence to suggest the opposite has been found in Great Britain, Belgium and Poland ${ }^{18}$.

Dietary guidelines recommend replacing high-fat milk with low-fat or skimmed milk. In our study, the differences in consumption of high-fat milk between the Baltic countries and Finland were especially large. High-fat milk is traditionally perceived as a healthy food in the Baltic countries. Higher educational achievement was associated with lower consumption of high-fat milk in all countries. A meta-analysis of data from surveys in nine European countries did not find enough evidence to support the inverse association between educational level and intake of high-fat milk ${ }^{19}$. However, they did find a higher level of consumption of skimmed milk among people belonging to higher occupational levels.

The consumption of cheese is perceived socially as a 'modern' nutritional habit. In our study, cheese was consumed more often in Finland than in the Baltic countries. The likelihood of eating cheese daily was directly associated with the level of education in Finland and Latvia. Similar trends were found in Estonia and Lithuania but they were not statistically significant and could be explained by the low prevalence of daily cheese consumption in these countries, especially in Lithuania. In many European countries, cheese is more commonly consumed by people with a high level of education than by those with a low level of education ${ }^{18,19}$

Daily consumption of meat and meat products was more common in the Baltic countries than in Finland. The frequent consumption of meat in the Baltic countries could be partly explained as being a legacy from the former Soviet Union, where a high intake of protein was considered necessary for good health. Almost half of the respondents to the Baltic Nutrition Survey (1997) believed that meat was an essential component for an everyday healthy $\operatorname{diet}^{24}$. The relationship between daily consumption of meat and educational level was inconsistent in the countries. Highly educated Finnish men and Lithuanian women consumed meat less often than those less educated, while the educational gradient was the opposite in Estonian men.

A number of studies have demonstrated that people with low and high level of education get their dietary fat from different sources ${ }^{10,18,19}$. These differences might have several explanations; people with a higher level of education are more concerned about their health, they have more knowledge about healthy nutrition and choose healthier foods more easily than people with a lower level of education $^{28-30}$. Highly educated people tend to choose modern foods, while those with a lower level of education consume more traditional foods ${ }^{31}$. They adopt new food habits faster than the less educated. Price is an important factor influencing food choice. Shortage of money, which is more common among people with a lower level of education, can restrict the consumption of healthy foods $^{32,33}$. When buying food, people with a higher level of education choose health over food price more frequently than those with a lower level of education ${ }^{28,29}$.

In conclusion, we found that the consumption of foods containing fat was related to educational level in all four countries studied. The diet of people with a higher level of 
education was more in line with recommendations on the consumption of foods containing saturated and unsaturated fats than that of people with less education. The educational gradient was more consistent in Finland than in the Baltic countries. Existing educational differences in the consumption of sources of fat should be considered in the development of national CVD prevention programmes.

\section{References}

1 World Health Organization. Global Strategy on Diet, Physical Activity and Health. Fifty-seventh Health Assembly, Resolution WHA 57.17 [online], 22 May 2004. Available at http:// www.who.int/gb/ebwha/pdf_files/WHA57/A57_R17-en. pdf. Accessed 9 September 2006.

2 World Health Organization (WHO). Diet, Nutrition and the Prevention of Chronic Diseases. Report of a WHO Expert Committee. WHO Technical Report Series No. 916. Geneva: WHO, 2003.

3 Nordic Medico-Statistical Committee (NOMESKO). Nordic/ Baltic Health Statistics 2002. Copenhagen: NOMESKO, 2002.

4 Kalediene R, Petrauskiene J. Inequalities in mortality by education and socio-economic transition in Lithuania: equal opportunities? Public Health 2005; 119: 808-15.

5 Kalędiene R, Petrauskiene J. Inequalities in life expectancy in Lithuania by level of education. Scandinavian Journal of Public Health 2000; 28: 4-9.

6 Kunst A, Leinsalu M, Kasmel A, Habicht J. Social Inequalities in Health in Estonia. Tallinn: Ministry of Social Affairs of Estonia, 2002.

7 Monden C. Socioeconomic inequalities in Latvia: a crosssectional study. Scandinavian Journal of Public Health 2004; 32: 217-23.

8 Valkonen T, Martikainen P, Jalovaara M, Koskinen S, Martelin T, Mäkelä P. Changes in socioeconomic inequalities in mortality during an economic boom and recession among middle-aged men and women in Finland. European Journal of Public Health 2000; 10: 274-80.

9 James WPT, Nelson M, Ralph A, Leather S. Socio-economic determinants of health. The contribution of nutrition to inequalities in health. British Medical Journal 1997; 314: 1545-9.

10 Roos E, Prättälä R, Lahelma E, Kleemola P, Pietinen P. Modern and healthy? Socioeconomic differences in the quality of diet. European Journal of Clinical Nutrition 1996; 50: 753-60.

11 Johansson L, Thelle DS, Solvoll K, Bjorneboe GE, Drevon CA. Healthy dietary habits in relation to social determinants and lifestyle factors. British Journal of Nutrition 1999; 81: 211-20.

12 Hulshof KFAM, Brussaard JH, Kruizinga AG, Telman J, Löwik MRH. Socio-economic status, dietary intake and $10 \mathrm{y}$ trends: the Dutch National Food Consumption Survey. European Journal of Clinical Nutrition 2003; 57: 128-37.

13 Kunst AE, Mackenbach JP. Measuring Socio-economic Inequalities in Health. Copenhagen: World Health Organization, 1993.

14 Galobardes B, Morabia A, Bernstein M. Diet and socioeconomic position: does the use of different indicators matter? International Journal of Epidemiology 2001; 30: 334-40.

15 Turrell G, Hewitt B, Patterson C, Oldenburg B. Measuring socio-economic position in dietary research: is choice of socio-economic indicator important? Public Health Nutrition 2002; 6: 191-200.

16 Roos E, Lahelma E, Virtanen M, Prättälä R, Pietinen P. Gender, socioeconomic status and family status as determinants of food behaviour. Social Science \& Medicine 1998; 46: 1519-29.

17 Lopez-Azpiazu I, Sanchez-Villegas A, Johansson L, Petkeviciene J, Prattala R, Martinez-Gonzalez MA. Disparities in food habits in Europe: systematic review of educational and occupational differences in the intake of fat. Journal of Human Nutrition \& Dietetics 2003; 16: 1-16.

18 Prättälä RS, Groth MV, Oltesdorf US, Roos GM, Sekula W, Tuomainen HM. Use of butter and cheese in 10 European countries. A case of contrasting educational differences. European Journal of Public Health 2003; 13: 124-32.

19 Sanchez-Vllegas A, Martinez JA, Prättälä R, Toledo E, Roos G, Martinez-Gonzalez MA for the FAIR-97-3096 group. A systematic review of socioeconomic differences in food habits in Europe: consumption of cheese and milk. European Journal of Clinical Nutrition 2003; 57: 917-29.

20 Prättälä R, Helasoja V and the Finbalt Group. Finbalt Health Monitor. Monitoring health behavior in Finland and Baltic countries. In: McQueen D, Puska P, eds. Global Behavioral Risk Factor Surveillance. New York: Kluwer Academic, 2003; 57-72.

21 Prättälä R, Helasoja V and the Finbalt Group. Finbalt Health Monitor. Feasibility of a Collaborative System for Monitoring Health Behavior in Finland and the Baltic Countries. Publications of the National Public Health Institute B21/1999. Helsinki: National Public Health Institute, 1999.

22 Männisto S, Ovaskainen M-L, Valsta L, eds. The National Findiet 2002 Study. Publications of the National Public Health Institute B3/2003. Helsinki: the National Public Health Institute, 2003.

23 World Health Organization (WHO). Nutrition and Lifestyle in the Baltic Republics: Summary Report. Copenhagen: WHO, 1999.

24 Pomerleau J, McKee M, Robertson A, Kadziauskiene K, Abaravicius A, Bartkeviciute R, et al. Dietary beliefs in the Baltic republics. Public Health Nutrition 2001; 4: 217-25.

25 Puska P, Helasoja V, Prattala R, Kasmel A, Klumbiene J. Health behaviour in Estonia, Finaland and Lithuania 1994-1998. Standardized comparison trend. European Journal of Public Health 2003; 13: 11-17.

26 Pietinen P, Vartiainen E, Seppanen R, Aro A, Puska P. Changes in diet, in Finland from 1972 to 1992: impact on coronary heart disease. Preventive Medicine 1996; 25: 243-50.

27 Pietinen P, Lahti-Koski M, Vartiainen E, Puska P. Nutrition and cardiovascular disease in Finland since the early 1970s: a success story. Journal of Nutrition, Health \& Aging 2001; 5 : $150-4$.

28 Hupkens CLH, Knibbe RA, Drop MJ. Social class differences in food consumption: the explanatory value of permissiveness and health and cost considerations. European Journal of Public Health 2000; 10: 108-13.

29 Kearney M, Kearney JM, Dunne A, Gibney MJ. Sociodemographic determinants of perceived influences on food choice in a nationally representative sample of Irish adults. Public Health Nutrition 2000; 3: 219-26.

30 Margetts BM, Martinez JA, Saba A, Holm I, Kearney M. Definitions of 'healthy eating', a pan EU survey of consumer attitudes to food, nutrition and health. European Journal of Clinical Nutrition 1997; 51: S23-9.

31 Prättälä R, Berg MA, Puska P. Diminishing or increasing contrasts? Social class variation in Finish food consumption patterns, 1997-1990. European Journal of Clinical Nutrition 1992; 46: 279-87.

32 Darmon N, Ferguson E, Briend A. A cost constraint alone has adverse effects on food selection and nutrient density: an analysis of human diets by linear programming. Journal of Nutrition 2002; 132: 3764-71.

33 Darmon N, Ferguson E, Briend A. Do economic constraints encourage the selection of energy dense diets? Appetite 2003; 41: 315-22. 